\title{
The Influence of Hypertension and High-Density Lipoprotein on the Diabetic Nephropathy Patients
}

\author{
Pengaruh Hipertensi dan Lipoprotein Densitas Tinggi pada Pasien Nefropati Diabetik \\ Enda Silvia Putri ${ }^{1 *}$, Marniati ${ }^{1}$, Arfah Husna ${ }^{1}$, Afriani Maifizar ${ }^{2}$ \\ 1Program Studi IImu Kesehatan Masyarakat, Fakultas Kesehatan Masyarakat, Universitas Teuku Umar, Jalan Alue \\ Peunyareng, Ujong Tanoh Darat, Mereubo, West Aceh, Aceh, Indonesia. \\ 2Program Studi Sosiologi, Fakultas IImu Sosial dan IImu Politik, Universitas Teuku Umar, Jalan Alue Peunyareng, Ujong \\ Tanoh Darat, Mereubo, West Aceh, Aceh, Indonesia.
}

DATA OF ARTICLE:

Received: 6 Sep 2019

Reviewed: 6 Nov 2019

Revised: 9 Jan 2020

Accepted: 11 Jan 2020

*CORRESPONDENCE:

endasilviaputri@utu.ac.id

DOI:

10.18196/mm.200139

TYPE OF ARTICLE:

Research
Abstract: Diabetes complication of kidney failure begins with poor control of HighDensity Lipoprotein (HDL) levels causing constriction of efferent arterioles affecting microalbuminuria, which triggers hypertension due to damage to blood vessels, with scarring in the filtration system of the central part of the kidneys. The Objective of the research was to analyze the influence of hypertension and HDL on the diabetic nephropathy patients. The study was an observational analytic study with a case-control design. The research sample consisted of 32 sample cases of patients with type II DM complications of kidney failure, and 32 control samples were DM type II patients without complications of kidney failure in dr. Pirngadi Hospital, Medan with accidental sampling technique. Data were generated by using questionnaires and medical records and analyzed by using the chi-square test, independent t-test, Mann-Whitney, and multivariate logistic regression to identify the effect of HDL and hypertension with DM type II complications of kidney failure. The Result of multivariate analysis showed hypertension OR; 17.845, and HDL OR; 7.049. The Conclusion showed that the most dominant factor that influenced the incidence of kidney failure complications in DM type II patients was hypertension at the Population Attributable Risk of 91\%.

Keywords: DM type II; High-Density Lipoprotein; Hypertension; Kidney failure

Abstrak: Diabetes komplikasi gagal ginjal diawali dengan kontrol kadar HDL yang buruk menyebabkan konstriksi arteriol eferen berpengaruh pada mikroalbuminuria yang memicu kejadian hipertensi merupakan akibat dari kerusakan pembuluh darah, dengan jaringan parut pada system filtrasi bagian utama dari ginjal. Tujuan penelitian adalah menganalisis pengaruh hipertensi dan HDL pada pasien nefropati diabetik. Metode penelitian adalah analitik observasional dengan desain kasus-kontrol, sampel penelitian terdiri dari 32 sampel kasus pasien DM Tipe II komplikasi gagal ginjal, dan 32 sampel kontrol pasien DM Tipe II tanpa komplikasi gagal ginjal di RSUD dr. Pirngadi, Medan dengan teknik accidental sampling. Data diperoleh dengan cara menggunakan kuisioner dan rekam medik serta dianalisis dengan menggunakan uji chi-square, independent t-test, mann-whitney, dan multivariat regresi logistik untuk melihat pengaruh HDL dan hipertensi dengan DM Tipe II komplikasi gagal ginjal. Hasil penelitian berdasarkan analisis multivariat diperoleh nilai risiko hipertensi OR: 17,845, HDL OR : 7,049. Kesimpulan penelitian ditemukan bahwa faktor yang paling dominan berpengaruh terhadap kasus DM Tipe II komplikasi gagagl ginjal adalah hipertensi dengan diperkuat nilai Population Attributable Risk 91\%.

Kata Kunci : DM tipe II; High-Density Lipoprotein; Hipertensi; Gagal ginjal 


\section{INTRODUCTION}

Diabetes mellitus (DM) is a collection of symptoms that arise in a person caused by an increase in blood glucose levels due to a decrease in progressive insulin secretion against the background of insulin resistance. ${ }^{1-5}$ In 2012, the World Health Organization (WHO) noted that in low and middle-income countries, more than $80 \%$ of deaths were caused by DM. By 2030 , it is predicted that more than two-thirds (70\%) of the global population will die from non-communicable diseases such as cancer, heart disease, stroke and DM. ${ }^{6,7}$

DM is the most common cause of kidney failure that almost $44 \%$ of cases exist. Although DM can be controlled, this disease can still cause kidney failure. In a serious case, DM causes $28.5 \%$ retinopathy and a $60 \%$ reduction in lower limbs. ${ }^{8,9}$ According to the 2014 International Diabetes Federation (IDF) data, in Indonesia, there was a $5.8 \%$ prevalence of DM. In 2013, Based on Basic Health Research or known as Riskesdas data, DM prevalence in Indonesia, based on interviews, diagnosed that it reached $1.5 \%$ and increased to $2.1 \%{ }^{10,11}$

The prevalence of DM in Indonesia based on interviews in 2013 was $2.1 \%$. This figure is higher than in 2007 , which was $1.1 \%$. A total of 31 provinces (93.9\%) showed a significant increase in DM

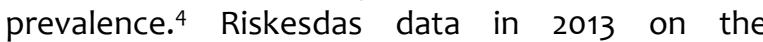
prevalence of DM in North Sumatra based on interviews diagnosed by doctors was $1.8 \%$. A doctor diagnoses DM with $2.3 \%$. The prevalence of DM patients in North Sumatra is almost close to the national average. North Sumatra has a prevalence of $5.3 \%$ or only $0.4 \%$ below the national average, which reached $5.7 \%$. Patients who previously have known that they have DM are only $26 \%$. Whereas most of those diagnosed with DM about 74\% did not know and that they suffered from previous DM. ${ }^{12}$

Based on the preliminary survey conducted at the dr. Pirngadi Hospital Medan, it was found the number of cases of DM with complications of kidney failure in 2012 as many as 20 cases, in 2013 as many as 6 cases, and in 2014 as many as 65 cases. Based on the description of the various literature above, it is necessary to research the cases of DM complications of kidney failure in $\mathrm{dr}$. Pirngadi Hospital Medan. Based on the background, this study aims to identify the risk factors that affect DM cases of complications of kidney failure in particular to analyze the influence of hypertension and HDL in the incidence of kidney failure complications in DM type II patients at dr. Pirngadi Hospital, Medan.

\section{MATERIALS AND METHOD}

The study was an observational analytic study with a case-control design. This study was conducted in dr. Pirngadi Hospital, Medan, in 2015. The population of the case was all patients with type II DM who had complications of kidney failure and visited the dr. Pirngadi Hospital, Medan, in 2015. The control population was that all type II DM patients had no complications of kidney failure who visited the dr. Pirngadi Hospital, Medan, in 2015.

The population in this study was all type II DM patients with complications of kidney failure who visited the dr. Pirngadi Hospital Medan with a total of 64 people. Case samples were obtained by calculating the sample size using the formula:

$\mathrm{n} 1=\mathrm{n} 2=\left[\frac{\frac{z \alpha}{2}+z \beta \sqrt{p q}}{p-\frac{1}{2}}\right]^{2}$ Where $p=\frac{O R}{1+O R}$

Information :

$\mathrm{n} 1=\mathrm{n} 2=$ Sample size

$a=$ Significance level of $5 \%$, then the value of $z=1.96$

$z a=$ Normal deviation value $\alpha 5 \%=1.96$

$z \beta=$ Normal deviation value $\beta 20 \%=0.842$

$\mathrm{OR}=$ Odds Ratio

$\mathrm{P}=$ Proportion of risk factors

$\mathrm{Q}=1-\mathrm{p}$

The sample size is based on several variables from previous studies, as shown in Table 1. Based on the results of the calculation, the maximum sample size of 29 after $10 \%$ of exposure is 32 people with DM type II complications of kidney failure. Therefore, the number of samples for the case group was 32 people with DM type II complications of kidney failure, and the control group was 32 people with DM type II without complications of kidney failure. The comparison of cases with controls was 1:1 matched by age and gender.

The analysis used in this study was bivariate analysis (Chi-square test, independent t-test, and Mann-Whitney test at a 95\% degree of confidence) to identify influence variable (HDL and Hypertension) to DM type II complications of kidney failure, multivariate analysis (multiple logistic regression tests at a $95 \%$ degree of confidence) to identify higher influence variable (HDL and Hypertension) to DM type II complications of kidney failure, and Population Attributable Risk (PAR) to identify the percentage of prevention that can be carried out.

Table 1. Sample Size based on Prior Research

\begin{tabular}{lcccc}
\hline Variables & OR & P & n1=n2 & n+10\% \\
\hline Family history & 6 & 0.001 & 13 & 14 \\
Exercise Practice & 8 & 0.004 & 11 & 12 \\
Blood Glucose Levels & 3 & 0.0001 & 29 & 32 \\
Systolic Blood Pressure & 14 & 0.0001 & 8 & 9 \\
\hline
\end{tabular}




\section{RESULT}

Table 2. The Frequency Distribution in dr. Pirngadi Hospital Medan based on The Risk Factors of Type II Diabetes Mellitus Patients

\begin{tabular}{lcccc}
\hline & \multicolumn{4}{c}{ DM Type II Complications of } \\
Changeable Risk Factors & \multicolumn{4}{c}{ Kidney Failure } \\
& Case & $\%$ & n & Control \\
\hline Average HDL & 23 & 71.9 & 9 & 28.1 \\
Not Good & 9 & 28.1 & 23 & 71.9 \\
Good & 32 & 100 & 32 & 100 \\
Total & 25 & 78.1 & 6 & 18.8 \\
\hline Hypertension & 7 & 21.9 & 26 & 81.2 \\
Yes & 32 & 100 & 32 & 100 \\
No & & & & \\
Total & & & & \\
\hline
\end{tabular}

In the univariate result in Table 2, the distribution of the average HDL in the highest HDL case group was not good ( $\leq 45 \mathrm{mg} / \mathrm{dl}$ ) with the proportion of $71.9 \%$, while the highest HDL control group is good $(>45 \mathrm{mg} / \mathrm{dl})$ with the proportion of 71.9\%. The highest distribution of hypertension in the case group in those with hypertension was $78.1 \%$, while the highest control group in those who did not have hypertension was $81.2 \%$.

In Table 3, it can be perceived that the ChiSquare test results show that the variables that influence the incidence of Type II DM complications failure kidney were average $\operatorname{HDL}(p=<0.001)$, hypertension $(p=<0.001)$.

Table 4 show that the results of different means show that there are significant differences in mean HDL, systolic, and diastolic blood pressure between cases with controls $(p<0.05)$.

In Table 5, the results of multiple logistic regression tests show HDL averages ( $p=0.022$ ), and hypertension ( $p=0.002$ affect the incidence of Type II DM complications of kidney failure). The most dominant variable affecting the incidence of kidney failure in Type II DM patients in dr. Pirngadi Hospital, Medan, is hypertension with a regression coefficient value of 2.882 and $\operatorname{Exp} B(O R) 17.845$.

Table 3. The Effect of Risk Factors on Type II DM Complications of Kidney Failure

\begin{tabular}{|c|c|c|c|c|c|c|}
\hline \multirow[t]{3}{*}{$\begin{array}{l}\text { Changeable } \\
\text { Risk Factors }\end{array}$} & \multicolumn{4}{|c|}{$\begin{array}{c}\text { DM Type II } \\
\text { Complications of } \\
\text { Kidney Failure }\end{array}$} & \multirow[t]{3}{*}{ P-Value } & \multirow{3}{*}{$\begin{array}{c}\text { OR } \\
(95 \% \mathrm{Cl})\end{array}$} \\
\hline & \multicolumn{2}{|c|}{ Case } & \multicolumn{2}{|c|}{ Control } & & \\
\hline & $\mathbf{n}$ & $\%$ & $\mathrm{n}$ & $\%$ & & \\
\hline \multicolumn{7}{|l|}{ Average } \\
\hline HDL Levels & & & & & \multirow{4}{*}{$<0.001$} & \multirow{4}{*}{$\begin{array}{c}2.55 \\
(1,53-4,24)\end{array}$} \\
\hline Not Good & 23 & 71.9 & 9 & 28.1 & & \\
\hline Good & 9 & 28.1 & 23 & 71.9 & & \\
\hline Total & 32 & 100 & 32 & 100 & & \\
\hline \multicolumn{7}{|l|}{ Hipertensi } \\
\hline Yes & 25 & 78.1 & 6 & 18.8 & \multirow{3}{*}{$<0.001$} & \multirow{3}{*}{$\begin{array}{c}4.00 \\
(2,30-6,93)\end{array}$} \\
\hline No & 7 & 21.9 & 26 & 81.2 & & \\
\hline Total & 32 & 100 & 32 & 100 & & \\
\hline
\end{tabular}

Table 4. The Differences in Mean Risk Factors That Can Be Changed by Type II DM Complications of Kidney Failure

\begin{tabular}{lcc}
\hline Variables & Mean & P-Value \\
\hline HDL $(\mathrm{mg} / \mathrm{dl})$ & 44.44 & $<0.001$ \\
Case & 70.19 & \\
Control & & \\
Systolic $(\mathrm{mmHg})$ & 147.78 & $<0.001$ \\
Case & 129.25 & \\
Control & & \\
Diastolic $(\mathrm{mmHg})$ & 86.00 & $<0.001$ \\
Case & 71.97 & \\
Control &
\end{tabular}

Table 5. The Final Results of Multiple Logistic Regression Tests

\begin{tabular}{lllcl} 
Variables & \multirow{2}{*}{$\mathrm{B}$} & Sig. & $\begin{array}{c}\text { Exp } \\
\mathrm{B}(\mathrm{OR})\end{array}$ & 95\% CI \\
\hline Average HDL & 1.953 & 0.022 & 7.049 & $1.327-37.433$ \\
Hypertension & 2.882 & 0.002 & 17.845 & $2.975-107.062$ \\
Konstanta & -4.325 & 0.000 & 0.013 & \\
\hline
\end{tabular}

It indicates that if Type II DM sufferers experience kidney failure 18 times, they are more likely to have hypertension than Type II DM patients who do not experience kidney failure.

The Percentage Correct value was $85.9 \%$, indicating that the average variable $\mathrm{HDL}$, hypertension, diet (diet), and duration of suffering from Type II DM explain the effect on the incidence of Type II DM complications of kidney failure in dr. Pirngadi Hospital, Medan is $85.9 \%$, while the remaining $14.1 \%$ is influenced by other factors not included in this research variable.

Calculating PAR value (Population Attributable Risk) on the most significantly influential variable with the highest OR (Odds Ratio). Hypertension, which is the most influential factor in the incidence of Type II DM complications of kidney failure, was obtained OR at 17.845 (95\% $\mathrm{Cl}=2.975-107.062)$ and $\mathrm{P}$ at 0.002 statistically significant.

Therefore, PAR values were:

$$
\begin{aligned}
\text { PAR } & =\frac{0,64(17,845-1)}{0,64(17,845-1)+1} \times 100 \% \\
& =91 \%
\end{aligned}
$$

It indicates that almost $91 \%$ of cases with the incidence of Type II DM complications of kidney failure can be prevented by correcting risk factors, namely hypertension, to normal blood pressure.

\section{DISCUSSION}

Based on the results of the bivariate analysis with independent t-test on systolic blood pressure and Mann-Whitney test on diastolic blood pressure, there were significant differences in mean systolic 
and diastolic blood pressure between Type II DM patients complicating kidney failure (cases) with uncomplicated Type II DM patients kidney failure (control) ( $p<0.05)$.

The result is in line with the result of the chisquare test where there is a relationship between hypertension and the incidence of Type II DM complications of kidney failure obtained $\mathrm{OR}=4.00$ (95\% Cl=2.30-6.93). It means that Type II DM patients who experience failure kidney have a chance of 4.00 times hypertension compared to Type II DM patients who do not experience kidney failure.

In line with the results of multivariate hypertension, the influence of the incidence of Type II DM complicating kidney failure was $\mathrm{OR}=17,845$ (95\% Cl=2,975-107,062), which indicates that Type II DM patients who had kidney failure had a chance of 17,845 times hypertension compared to Type II DM patients who did not experience kidney failure.

It is also in line with Arsono's research, 2015, in Prof. Dr. Margono Soekarjo Hospital Purwokerto which showed that the analysis of the influence of hypertension with the incidence of Type II DM complications of kidney failure obtained $O R=14,15$. The result indicates that Type II DM patients who experience kidney failure have a chance of 14.15 times hypertension (systolic blood pressure 2140mmHg) compared to DM patients II who did not experience kidney failure. Furthermore, it statistically explained that there was a significant effect with a value of $p<0.05 .^{13}$

Likewise, in the analysis of the influence of hypertension with the incidence of Type II DM complications of kidney failure which obtained $\mathrm{OR}=10.00$, it means that Type II DM patients who have kidney failure have a chance of 10.00 times hypertension (diastolic blood pressure $\geq 90 \mathrm{mmHg}$ ) compared to Type II DM patients who do not experience kidney failure and it statistically explained that there was a significant effect with a value of $p<0.05 .^{13}$ The results are in line with the research conducted by Dewi (2014) stating that the hypertension was influenced by diabetes. ${ }^{14}$

According to another research by Wang (2017), diabetes mellitus and hypertension are major risk factors for chronic kidney injury, accounting with $>70 \%$ of end-stage kidney disease. ${ }^{15}$ In this study, we assessed interactions of hypertension and diabetes in causing kidney dysfunction, injury, and the role of endoplasmic reticulum (ER) stress. Hypertension was induced by aorta constriction (AC) between the renal arteries in 6-month old male Goto-Kakizaki (GK) type 2 diabetic and control Wistar rats. Fasting plasma glucose averaged $162 \pm 11$ and $87 \pm 2 \mathrm{mg} / \mathrm{dL}$ in GK and Wistar rats, respectively. AC produced hypertension in the right kidney (above $A C$ ) and near-normal blood pressure (BP) in the left kidney (below $A C$ ), with both kidneys exposed to the same levels of glucose, circulating hormones, and neural influences. After 8 wks of AC, BP above the AC (and in the right kidney) increased from $109 \pm 1$ to $152 \pm 5 \mathrm{mmHg}$ in GK rats and from $106 \pm 4$ to $141 \pm 5 \mathrm{mmHg}$ in Wistar rats. The diabetic-hypertensive right kidneys in GK-AC rats had much more significant increases in albumin excretion and histological injury compared to left kidneys (diabetes only) of GK rats in the right kidneys (hypertension only) of Wistar-AC rats. The increase in ER stress and oxidative stress indicators was observed in diabetic-hypertensive kidneys of GK-AC rats. Inhibition of ER stress with tauroursodeoxycholic acid (TUDCA) for 6 wks reduced $B P(135 \pm 4$ vs. $151 \pm 4 \mathrm{mmHg})$, albumin excretion, ER and oxidative stress, and glomerular injury. Meanwhile, it increases GFR in hypertensivediabetic kidneys. These results suggest that diabetes and hypertension interact synergistically to promote kidney dysfunction and injury via ER stress. ${ }^{15}$

Having the highest PAR value of $91 \%$ indicates that almost $91 \%$ of cases with the incidence of Type II DM complications of kidney failure can be prevented by improving hypertension to have normal blood pressure. Furthermore, other research results show that hypertension was one of the many risk factors for diabetes. ${ }^{16}$ Other factors, such as HDL, LDL, triglycerides, can also contribute to the number of diabetes cases. Mengyang stated that, based on the results of his research, it could prevent diabetes by controlling these factors. ${ }^{16}$

The multivariate results of average HDL influence the incidence of Type II DM complications of kidney failure, which obtained OR $=7.049$ (95\% $\mathrm{Cl}=1.327-37,433)$. It indicates that Type II DM patients who experience kidney failure have a chance of 7.049 times, and the average HDL is not good ( $\leq 45 \mathrm{mg} / \mathrm{dl}$ ) compared to Type II DM patients who did not experience kidney failure. In line with Rodriguez-Poncelas's research conducted in 2013 at the Spanish Hospital, it revealed the $p$-value $=0.001$ ( $p$ <.05), indicating that HDL influences the incidence of Type II DM complications of kidney failure. ${ }^{22}$

On the other hand, it also showed a PAR value of $78 \%$ indicating that nearly $78 \%$ of cases with the incidence of Type II DM complications of kidney failure can be prevented by improving the poor quality of average HDL $(\leq 45 \mathrm{mg} / \mathrm{dl})$ to have a good quality (>45mg / dl). 
Moreover, High-density lipoprotein (HDL) has many antioxidant roles. ${ }^{17}$ The role of antioxidants in HDL is better with the support of the consumption of vegetables and fruit in patients with Type 2 diabetes to prevent complications. ${ }^{17}$ Another research obtained results showing that the function of HDL as an anti-inflammatory can work effectively on patients with Type 2 DM before the patient has complications. $^{23}$ However, its function will deteriorate if the condition of Type $2 \mathrm{DM}$ patients is with complications. ${ }^{18}$

The research by Nair (2016) in Pima Indian aims to look at protective factors for Type $2 \mathrm{DM}$ in women. ${ }^{19}$ Based on the results of his research, it revealed that 12 of 21 women in Pima Indian showed a significant relationship between HDL and the incidence of Type 2 DM. ${ }^{19}$ In line with it, another research by Gourgari et al. (2019) stated that there are HDL influences on diabetes cases with a $\mathrm{P}$ value $=0.0001 .^{20}$ It is in line with another research stating that low HDL levels affect the incidence of diabetes with OR $(6,818, \mathrm{P}=0.002) .{ }^{20,21,24}$

\section{CONCLUSION}

Based on the results of this study, it can be concluded that there was an influence of Hypertension on the incidence of Type II DM complications of kidney failure in $\mathrm{dr}$. Pirngadi Hospital, Medan $(\mathrm{OR}=17,845(95 \% \mathrm{Cl}=2,975$ 107,062), and there was an influence of HDL on the incidence of Type II DM complications of kidney failure in dr. Pirngadi Hospital, Medan (OR = 7.049 $(95 \% \mathrm{Cl}=1.327-37,433)$.

\section{ETHICAL CONSIDERATION}

Ethical Consideration Number: 478/V/SP/2015, Subject: Approval of the USU Nursing Faculty health research ethics committee, University Of North Sumatera

\section{REFERENCES}

1. Waspadji S. Komplikasi Diabetes Tipe 2: Pencegahan dan Penanganannya. Jakarta: Badan Penerbit FKUI; 2014.

2. Papadakis M.A, Mcphee S.J. Current Medical Diagnosis and Treatment. USA: McGraw Hill Companies; 2014.

3. Davey P. At a Glance Medicine Jakarta: Erlangga; 2012.

4. Price S.A, Wilson L.M. Patofisiologi Konsep Klinis Proses-Proses Penyakit, Edisi Keenam. Jakarta: EGC; 2012.

5. Rubenstein D, Wayne D, Bradley J. Lecture Notes: Kedokteran Klinis. Jakarta: Erlangga; 2012.

6. World Health Organization (WHO). Diabetes.
Geneva; 2014. https://www.who.int/newsroom/fact-sheets/detail/diabetes

7. Kementerian Kesehatan Republik Indonesia. Profil Kesehatan Indonesia Tahun 2013. Jakarta: Kementerian Kesehatan Republik Indonesia. 2012.

8. Kern, T. S., Berkowitz, B. A., \& Feldman, E. L. National Institute of Diabetes and Digestive and Kidney Diseases (NIDDK) meeting summary: Advances toward measuring diabetic retinopathy and neuropathy: from the bench to the clinic and back again (April 4-5, 2007, Baltimore, Maryland). Journal of Diabetes and its Complications, 2009; 23 (3): 219-223.

9. American Diabetes Association (ADA). Statistics About Diabetes. America, 2014.

https://www.diabetes.org/resources/statistics/stati stics-about-diabetes

10. Atlas, D. International diabetes federation. IDF Diabetes Atlas, 7th edn. Brussels, Belgium: International Diabetes Federation. 2015.

11. Kementerian Kesehatan Republik Indonesia. Buletin Jendela dan Data Informasi Kesehatan Penyakit Tidak Menular. Jakarta, 2012.

12. Badan Penelitian dan Pengembangan Kesehatan Dasar Departemen KesehatanRepublik Indonesia. Riset Kesehatan Dasar 2013. Jakarta, 2012.

13. Arsono, S. Diabetes Melitus Sebagai Faktor Risiko Kejadian Gagal Ginjal Terminal (Studi Kasus Pada Pasien Rsud Prof. dr. Margono Soekarto Purwokerto) (Doctoral dissertation, Program Pascasarjana Universitas Diponegoro). 2005.

14. Dewi, R. P. Faktor risiko perilaku yang berhubungan dengan kadar gula darah pada penderita diabetes melitus tipe 2 di RSUD Kabupaten Karanganyar. Jurnal Kesehatan Masyarakat Universitas Diponegoro, 2013; 2(1), 18824.

15. Wang, Z., do Carmo, J. M., Aberdein, N., Zhou, X., Williams, J. M., Da Silva, A. A., \& Hall, J. E. Synergistic interaction of hypertension and diabetes in promoting kidney injury and the role of endoplasmic reticulum stress. Hypertension, 2017; 69(5), 879-891.

16. Hong, M., Ling, Y., Lu, Z., Liu, Y., Gu, P., Shao, J., ... \& Li, X. Contribution and interaction of the low-density lipoprotein cholesterol to high-density lipoprotein cholesterol ratio and triglyceride to diabetes in hypertensive patients: A cross-sectional study. Journal of diabetes investigation, 2019; 10(1), 131-138.

17. Daniels, J. A., Mulligan, C., McCance, D., Woodside, J. V., Patterson, C., Young, I. S., \& McEneny, J. A randomized controlled trial of increasing fruit and vegetable intake and how this influences the carotenoid concentration and 
activities of PON-1 and LCAT in HDL from subjects with type 2 diabetes. Cardiovascular diabetology, 2014; 13(1), 1-9.

18. Sun, J. T., Liu, Y., Lu, L., Liu, H. J., Shen, W. F., Yang, K., \& Zhang, R. Y. Diabetes-invoked highdensity lipoprotein and its association with coronary artery disease in patients with type 2 diabetes mellitus. The American journal of cardiology, 2016; 118 (11): 1674-1679.

19. Nair, A. K., Piaggi, P., McLean, N. A., Kaur, M., Kobes, S., Knowler, W. C., ... \& Baier, L. J. Assessment of established HDL-C loci for association with HDL-C levels and type 2 diabetes in Pima Indians. Diabetologia, 2016; 59 (3): 481-491.

20. Gourgari, E., Ma, J., Playford, M. P., Mehta, N. N., Goldman, R., Remaley, A. T., \& Gordon, S. M. Proteomic alterations of HDL in youth with type 1 diabetes and their associations with glycemic control: a case-control study. Cardiovascular diabetology, 2019; 18 (1): 43.

21. Luo, Y., Li, J., Zhang, J., \& Xu, Y. Low HDL cholesterol is correlated to the acute ischemic stroke with diabetes mellitus. Lipids in health and disease, 2014; 13 (1): 171.

22. Rodriguez-Poncelas, A., Garre-Olmo, J., FranchNadal, J., Diez-Espino, J., Mundet-Tuduri, X., Barrot-De la Puente, J., \& Coll-de Tuero, G. Prevalence of chronic kidney disease in patients with type 2 diabetes in Spain: PERCEDIME2 study. BMC nephrology, 2013; 14 (1), 46.

23. Mao, J. Y., Sun, J. T., Yang, K., Shen, W. F., Lu, L., Zhang, R. Y., ... \& Liu, Y. Serum amyloid A enrichment impairs the anti-inflammatory ability of HDL from diabetic nephropathy patients. Journal of Diabetes and its Complications, 2017; 31(10): 1538-1543.

24. Luo, C., Zhang, Y., Ding, Y., Shan, Z., Chen, S., Yu, M., ... \& Liu, L. Nut consumption and risk of type 2 diabetes, cardiovascular disease, and allcause mortality: a systematic review and metaanalysis. The American journal of clinical nutrition, 2014; 100(1): 256-269. 